\title{
Modal sosial paguyuban dalam pengembangan fasilitas pendidikan di sekolah dasar
}

\author{
Yolanda Stepy $^{1}$, Firman Firman ${ }^{2}$ \\ ${ }^{1}$ Pascasarjana, Universitas Negeri Padang. \\ ${ }^{2}$ Universitas Negeri Padang.
}

\begin{abstract}
This study aimed to describe the social capital of the community in developing educational facilities in SD Negeri 005 State Petapahan Jaya, Kampar District. With the reality of a heterogeneous population inhabited by self-employed trans-migrants consisting of Sundanese, Batak, Minang, Malay, and Javanese. Economically the village had developed significantly, especially since the opening of the Palm Oil plantation. This research used a qualitative approach. Data collection was done through observation, interviews and document use. Data analysis techniques used in this study are data reduction, data presentation and conclusion drawing. The results of this study indicate that there were three elements of community social capital in developing educational facilities in SD Negeri 005 Petapahan Jaya, Kampar Regency: (1) Social Networking, in the form of community participation and solidarity (2) Trust in the form of honesty and cooperation (3) The existence of norms that jointly owned.
\end{abstract}

Keywords: social capital, circle of friends, facility development.

This is an open access article distributed under the Creative Commons Attribution License, which permits unrestricted use,
distribution, and reproduction in any medium, provided the original work is properly cited. C2020 by author

\section{PENDAHULUAN}

Proses pembangunan sumber daya manusia (SDM) akan terwujud melalui pendidikan itu sendiri baik pendidikan formal UU No 20 tahun 2003, Sesuai dengan pasal 1 ayat 11 menyebutkan Bahwa yang dimaksud pendidikan Formal adalah jalur pendidikan yang terstruktur dan berjenjang yang terdiri atas pendidikan dasar, pendidikan menengah dan pendidikan tinggi maupun pendidikan non formal. (Imron). UU No 20 tahun 2003 Pendidikan Non formal menurut pasal 1 ayat 12 menyebutkan bahwa penddikan diluar pendidikan formal yang dapat dilaksanakan secara terstruktur dan berjenjang sehingga pendidikan dianggap penting bagi manusia (Hermawan).

Menyadari pentingnya proses peningkatan kualitas sumber daya manusia melalui pendidikan, maka pemerintah sudah seharusnya mewujudkan pendidikan melalui usaha pembangunan pendidikan bermutu dengan menyiapkan sarana dan prasarana sesuai amanah Undang-undang Republik Indonesia Tentang Sistem Pendidikan Nasional mengamanatkan bahwa pemerintah harus menyediakan saran dan prasarana pendidikan, yang memenuhi keperluan pendidikan sesuai dengan pertumbuhan dan perkembangan potensi fisik, kecerdasan intelektual, sosial, emosional dan kewajiban peserta didik. (Permendikbud RI No. 20)

Undang-undang diatas memberi pesan bahwa negara mempunyai kewajiban menyediakan sarana dan prasarana dalam proses pendidikan. Dalam kamus besar bahasa Indonesia dikatakan bahwa sarana adalah segala sesuatu yang dipakai sebagai alat dalam mencapai maksud dan tujuan sedangkan prasarana adalah merupakan penunjang terselenggaranya satu proses usaha, pembangunan, proyek, dsb (Tim Kamus Badan Pengembangan dan Pembinaan Bahasa). Menurut Departemen Pendidikan dan Kebudayaan yang dimaksud dengan sarana pendidikan adalah semua fasilitas yang diperlukan dalam proses belajar mengajar baik yang bergerak maupun 
tidak bergerak agar pencapaian tujuan pendidikan dapat berjalan dengan lancar, teratur, efektif dan efisien. (Nurhadi).

Membangun sarana pendidikan yang berkualitas juga merupakan peran aktif masyarakat sekitar dalam prosesnya. Dalam hal ini pendidikan perlu didudukkan sebagai sebuah nilai yang tumbuh dan berkembang di masyarakat. Jika nilai pengetahuan menjadi dominan dalam setiap gerak masyarakat, dengan sendirinya masyarakat akan termotivasi dalam menuntut dan mengembangkan ilmu pengetahuan. (Sulistyorini, 2011)

Pelibatan masyarakat dalam proses pembangunan dan pengembangan sarana pendidikan menjadi penting mengingat sekolah merupakan bagian dalam sistem sosial yang berfungsi sebagai agen transfer norma dan transfer nilai pada peserta didik. Sehingga pelibatan masyarakat menjadi satu hal yang penting bagi terselenggaranya proses pendidikan yang berkualitas. Masyarakat dapat dilibatkan melalui pemberian bantuan, gotong royong serta ikut dalam program sekolah. pada tataran kelembagaan perwakilan masyarakat melalui komite sekolah juga dianggap penting dalam pelibatan masyarakat. (Pariwisata, 2014)

Terwujudnya pendidikan yang berkualitas dapat diwujudkan dengan kerjasama antar elemen baik pemerintah, swasta, dan masyarakat. Pelibatan masyarakat tidak hanya dalam bentuk bantuan fisik (capital) tetapi juga berwujud modal sosial (capital social) sebagai kunci bagi pembangunan dan pengembangan pendidikan yang berkualitas. Modal sosial adalah sumber daya yang dapat dipandang sebagai investasi untuk mendapatkan sumber daya baru. Seperti diketahui bahwa sesuatu yang disebut sumber daya (resources) adalah sesuatu yang dapat dipergunakan untuk dikonsumsi, disimpan dan diinvestasikan. Sumber daya yang digunakan untuk investasi disebut sebagai modal. Pada modal sosial lebih menekankan pada potensi kelompok dan antar kelompok dengan ruang perhatian pada jaringan sosial, norma, nilai, dan kepercayaan antar sesama yang lahir dari anggota kelompok dan menjadi norma kelompok (Simarmata, 2009)

Putnam (1993) Menyebutkan bahwa modal sosial menunjuk pada bagian-bagian organisasi sosial seperti kepercayaan, norma dan jaringan, yang dapat meningkatkan efisiensi masyarakat dengan memfasilitasi tindakan-tindakan yang terkoordinasi. Menurut Putnam, kerjasama sukarela lebih mudah terjadi didalam komunitas yang telah mewarisi sejumlah modal sosial dalam bentuk aturan-aturan, pertukaran timbal balik (reciprocity), dan jaringan-jaringan kesepakatan antar anggota dalam kelompok. Perspektif Putnam tentang modal sosial lebih focus pada tingkat keluarga dan komunitas serta menekankan pentingnya hubungan antara individu yang kuat disertai dengan tingkat responsibility yang tinggi. (Primadona).

Desa petapahan Jaya adalah sebuah desa tranmigrasi swakarsa pada tahun 1984, diman apada periode awal, penduduk merupakan tranmigrasi yang bersala dari rokan, jawa timur, jawa tengah Desa Petapahan Jaya salah satu desa yang berda di Kecamatan tapung Kabupaten kampar Provinsi Riau, secara ekonomi desa ini berkembang secara signifikan terutama sejak dibukanya perkebunan kelapa sawit.

Desa Petapahan Jaya mempunyai penduduk cukup heterogen suku Sunda, suku Batak, Suku Minang, suku Melayu dan Suku Jawa. Namun mayoritas warga Desa ini adalah suku Jawa. Karakteristik Desa Petapahan Jaya sebagai daerah pedesaan mempunyai kearifan lokal yang mempu mendorong pengembangan pendidikan kususnya lembaga Pendidikan di Sekitarnya.SD Negeri 005 Petapahan Jaya sebagai lembaga pendidikan tempat menyekolahkan anak-anak penduduk sekitarnya tentu menjadi potensi masyarakat untuk dilibatkan dalam pengembangan lembaga tersebut. Apalagi sejarah berdirinya SD Negeri 005 Petapahan Jaya dibangun atas Inisiasi dari warga sekitar.

Oleh sebab itu penulis tertarik untuk membahas "Modal Sosial Paguyuban Di Lingkungan Masyarakat Transmigrasi dalam Pengembangan Fasilitas Pendidikan Di SD Negeri 005 Petapahan Jaya Kabupaten Kampar".

\section{METODE}

Penelitian ini menggunakan pendekatan kualitatif agar dapat mendeskripsikan modal sosial paguyuban di lingkungan masyarakat transmigrasi dalam pengembangan fasilitas pendidikan di SD Negeri 005 Petapahan Jaya Kabupaten Kampar dengan seluas-luasnya dengan sedalam mungkin sesuai variasi yang ada sehingga peneliti mampu mendepkripsikan fenomena secara utuh. Data berupa kata-kata tertulis atau lisan di peroleh dari orang-orang dan perilaku yang dapat diamati melalui pengamatan, wawancara dan pemanfaatan dokumen. 
Selanjutnya triangulasi dilakukan dengan cara membandingkan data hasil pengamatan dan wawancara dengan hasil wawancara yang diperoleh kemudian peneliti membaca dan memeriksanya secara berulang kali. Teknik analisis yang digunakan dalam penelitian ini yaitu reduksi data, penyajian data dan penarikan kesimpulan.

\section{HASIL DAN PEMBAHASAN}

Jaringan social (social networking)

Jaringan sosial sebagai unsur modal sosial, jaringan sosial dapat terbentuk karena ada nilai dan norma yang kemudian melandasi lahirnya kerja sama, jaringan dan kerja sama tidak dapat dipisahkan, jaringan sosial yang terdapat di paguyuban masyarakat di SD Negeri 005 Petapahan Jaya dalam pengembanagan fasilitas terjadi berkat adanya keterkaitan antara individu di dalam komunitas berupa partisipasi dan solidaritas..

\section{Partisipasi (Participations)}

Paguyuban masyarakat di Desa Petapahan Jaya dalam partisipasinya paguyuban mendapat partisipasi dari semua elemen masyakat yang ada di Desa Petapahan Jaya untuk pengembangan fasilitas di SD Negeri 005 Petapahan Jaya ini dimana partisipasi tersebut dirasakan oleh seluruh masyarakat yang berada di Desa Petapahan jaya untuk pengembangan fasilitas di SD negeri 005 Petapahan Jaya.

Paguyuban di SD Negeri 005 Petapahan Jaya di dalamnya terdapat partispasi dan juga jaringan sosial di dalamnya, dimana paguyuban dalam mengembangkan fasilitas pendidikan masyarakat selau turut serta dalam melakukan pengembangan fasilitas di sekolah, dimana paguyuban masyarakat ini memiliki inisiatif untuk turut serta malakukan pengembangan fasilitas di sekolah seperti yang di kemukakan Pak Nasrudin sebagai berikut: "Paguyuban selalu ikut berpartisipasi dalam segala kegiatan sekolah, baik itu dalam pembangunan, atau ketika sekolah memiliki acara sekolah, paguyuban selalu ikut serta dan berpartisipasi untuk sekolah"

Berdasarkan hasil wawancara bersama Pak Nasrudin bahwasanya bentuk modal sosial yang terjadi di paguyuban masyarakat di SD Negeri 005 Petapahan Jaya yaitu partispasi paguyuban dalam ikut serta melakukan segala kegiatan-kegiatan yang dilakukan oleh sekolah, partisipasi paguyuban masyarakat ini tidak hanya sebatas kegiatan sekolah saja melainkan dalam melakukan sumbangan sukarela dimana sumbangan sukarela ini merupakan bentuk dari partisipasi paguyuban masyarakat dalam mengembangkan fasilitas di SD Negeri 005 Petapahan Jaya, seperti yang di kemukakan Pak Nawi sebagai berikut: "Dalam mengembangkan fasilitas sekolah partisipasi masyarkat tidak hanya sebatas keikut sertaan saja melainkan partisipasi dalam finansial karena kan kita kadang ada sumbangan untuk kegiatan"

Berdasarkan hasil wawancara dengan Pak Nawi bahwasanya partisipasi masyarakat dalam pengembangan fasilitas di SD Negeri 005 Petapahan Jaya tidak hanya sebatas keikut sertaan saja melainkan pastisipasi masyarakat juga dalam segi finansial, dimana pasrtisipasi dari segi finansial ini berbentuk sumbangan sukarela yang di lakukan paguyuban untuk mengembangakan fasilitas seklolah. Sehingga partisipasi dalam pengembangan fasilitas di sekolah tidak hanya sebatas keikut sertaan masyarakat saja melainkan masyarakat melakukan sumbangan sukarela agar terlaksananya pengembangan fasilitas di SD Negeri 005 Petapahan Jaya.

\section{Solidaritas (Solidarity)}

Paguyuban di SD Negeri 005 Petapahan Jaya selain di dalamnya terdapat partispasi dan juga terdapat solidaritas, dimana solidaritas merupakan faktor utama dalam merekatkan hubungan sosial dalam paguyuban masyarakat dalam mengembangkan fasilitas pendidikan di SD Negeri 005 Petapahan Jaya karena paguyuban masyarakat memiliki rasa keterikatan atau kekeluargaan satu sama lain karena mimilki kepentingan, tujuan dan kewajiban yang sama, seperti yang di kemukekan oleh Buk Khanah sebagai berikut:"paguyuan masyakat kita merasa bersama sama ingin melakukan pengembangan sekolah, tidak ada perbedaan siapa saja boleh silahkan selagi itu untuk kemajuan sekolah, lagian dengan kita paguyuban gini kita lebih merasa sebagai keluarga dan juga sebagai tempat kita silahturahmi antar sesama jadi kita saling kenal"

Berdasarkan hasil wawancara bersama Buk Khanah bahwasannya solidaritas di paguyban masyarakat dalam pengembangan fasilitas di SD Negeri 005 Petapahan Jaya terjadi karena ada rasa kekeluargaan sara sepemikiran dan setujuan sehingga hal itulah tadi yang membuat paguyuban masyarakat sehingga melakukan pengembangan fasilitas di SD Negeri 005 Petapahan Jaya, selain itu juga solidaritas ini untuk sebagai tempat silaturahmi antar masyarakat agar lebih menganal satu dengan yang lainnya. Pendapat yang senada juga di sampaikan oleh Pak Dodi sebagai berikut: "Dengan keikut sertaan kita dalam paguyuban masyarakat ini itu karena dasarnya kita memiliki keinginan yang sama tujuan yang sama dan saling percaya satu dengan lainnya, karena paguyuban ini juga kita merasa kita lebih kompak sesama masyarakat lebih ada rasa kekeluargaan saling 
perduli terhadap sesama dan pada akhirnya kita peka terhadap lingkungan sekitar terutama ya dalam pengembangan fasilitas di sekolah ini”,

Berdasarkan hasil wawancara bersama pak Dodi bahwasaanya paguyuban masyarakat pada dasarnya terjadi karena memiliki keinginan atau tujuan yang sama dan selain itu juga memiliki kepercayaan antara masyarakat yang satu dengan masyarakat lainnya, selain itu dengan adanya paguyuban masyarakat ini masyakarat mejadi lebih kompak dan lebih memiliki rasa kekeluargaan dan pada akhirnya terpupuklah rasa keperdulian antar sesama dan oeka terhadapa lingkungan sekitar terutama dalam pengembangan fasilitas di SD Negeri 005 Petapahan Jaya.

Jaringan sosial sosial juga terjadi dalam pengembangan fasilitas di SD Negeri 005 Petapahan Jaya jaringan sosial ini terjadi karena adanya keterkaitan antar individu dan paguyuban masyarakat, jaringan sosial sosial yang terjadi di paguyuban masyarakat ini sangat di butuhkan karena jaringan sosial antar sesama paguyuban masyarakat dengan pihak-pihak terkait sangat di butuhkan karena dengan adanya jaringan sosial ini mempermudah paguyuban masyarakat untuk meminta sumbangan sukarela apabila paguyuban masyarakat membutuhkan dana atau bahan yang digunakan dalam pengembangan fasilitas dalam hal ini di sampaikan oleh Pak Jumari sebagai berikut:"Untuk pengembangan selain kita sendiri dari paguyuban membuat sumbangan sukarela apabila dana yang dibutuhkan masih kurang atau bahan-bahan untuk pengembangan masih kurang kita biasanya meminta bantuan kepada dunia usaha, seperti KUD, Pabrik Kelapa Sawit dan juga dunia usaha lainnya untuk membantu memberikan sumbangan sukarela untuk pengembangan fasilitas sekolah"

Berdasarkan hasil wawancara dengan Pak Jumari bahwasanya paguyuban membentuk sebuah jaringan dengan dunia usaha untuk pengembangan fasilitas sekolah selain melakukan sumbangan sukarela bersama masyarakatnya paguyuban juga memiliki jaringan sosial dengan berbagai dunia usaha seperti Koperasi Unit Desa, Pabrik Kelapa Sawit dan juga dunia usaha yang berada di Desa Petapahan Jaya. Pendapat yang senada juga di sampaikan oleh $\mathrm{Bu}$ Kahanah sebagai berikut: "Paguyuban masyarakat dalam melakukan kegiatannya kita ya meminta bantuan kepada pihak-pihak yang kami rasa bisa membantu dalam pengembangan fasiliutas di sekolah selain kami melakukan sumbangan juga kami meminta bantuan kepada dunia usaha KUD, Pabrik, juga toko-toko yang ada di Desa Petapahan Jaya ini"

Berdasarkan hasil wawancara bersama Buk Khanah bahwasaanya dalam memenuhi kebutuhan untuk pengembangan fasilitas di sekolah paguyuban melakukan sumbangan sukarela dan juga meminta bantuan kepada dunia usaha yang ada di Desa Petapahan Jaya seperti Koperasi Unit Desa, Pabrik, juga toko yang ada di desa Petapahan Jaya.

Dengan adanya pelibatan dunia usaha yang ada di Desa Petapahan Jaya maka tercipta kekompakan dan solidaritas antar warganya. Sehingga modal sosial kuat tergantung pada kapasitas suatau individu membangun suatu jaringan dalam suatu kelompok, kunci keberhasilan dari modal sosial dalam jaringan ini terletak pada kemampuan seseorang dalam suatu perkumpulan melibatkan diri dalam suatu hubungan sosial

\section{Kepercayaan (Trust)}

Paguyuban masyarakat di Desa Petapahan Jaya berdasarkan pengamatan peneliti tingkat kepercayaan antara warganya sangat baik dimana terlihat kerjasama antar paguyuban masyarakatnya sangat baik, kepercayaan paguyuban masyarakat ini merupakan unsur yang sangat penting ada dalam modal sosial, karena dengan adanya kepercayaan orang-orang akan dapat melaksanakan atau bekerja sama secara baik dan efektif dalam hal ini di sampaikan oleh Pak Nasrudi sebagai berikut: "sampai saat ini ketika paguyuban meminta bantuan kepada masyarakat maupun dunia usaha selalu mendapatkan respon yang baik dan alhamdulillah tidak pernah itu ketika kita minta bantuan secara sukarela mereka tidak memberi, bahkan kadang sudah menyumbang dana di tambah lagi dengan menyumbang bahan-bahan yang kita perlukan dalam pengembangan fasilitas"

Berdasarkan hasil wawancara bersama Pak Nasrudin bahwasaanya selama ada paguyuban ini ketika paguyuban meminta bantuan kepada masyarakat ataupun dunia usaha paguyuban tidak pernah masyarakat dan dunia usaha tidak memberikannya bahkan terkadang sudah memberi sumbangan secara sukarela berbentuk uang diberi lagi barang atau kebutuhan yang diperlukan untuk pengembangan sekolah kepada paguyuban ini. Pendapat yang senada juga di sampaikan oleh Pak Ade sebagai berikit: "Kalau paguyuban meminta sumbangan sukarela masyarkat selalu memberikan tidak ada yang keberatan, karena kita percaya, kita bisa lihat hasil kerjanya paguyuban masyarakat ini, jadi paguyuban ketika meminta sumbangan sukarela tidak pernah masyarakat atau dunia usaha keberatan untuk memebrikannya"

Berdasarkkan hasil wawancara yang dilakukan dengan Pak Ade bawasannya masyarakat sudah percaya atas kinerja paguyuban masyarakat ini dalam pengembangan fasilitas pendidikan di SD Negeri 005 Petapahan 
Jaya, dimana ketika paguyuban ini memeinta sumbangan dana secara sukarela tidak ada pernah masyarakat atau dunia usaha yang keberatan untuk memberikannya, hal ini di karenakan hasil dari pengembangan fasilitas di SD Negeri 005 Petapahan Jaya kelihatan hasilnya atau dapat dirasakan oleh masyarakat dan dunia usaha yang telah memberikan sumbangan.

Kepercayaan adalah suatu yang dipertukarkan dengan berlandaskan norma bersama demi kepetingan orang banyak. Kepercayaan menyangkut hubungan timbal balik maksudnya ialah kepercayaan akan semakin baik apabila masing-masing pihak memiliki pengharapan yang sama-sama terpenuhi oleh kedua belah pihak, maka dengan begitu tingkat kepercayaan yang tinggi akan terwujud, dalam hal ini paguyuban di SD Negeri 005 Petapahan Jaya. Selanjutnya kepercayaan ini lebih konkrit ditunjukkan masyarakat melalui kejujuran dan kerjasama yang baik.

\section{Kejujuran (Honesty)}

Berdasarkan hasil wawancara dan observasi dilapangan paguyuban masyarakat di Desa Petapahan Jaya kejujuran merupakan hal yang benar-benar di junjung tinggi oleh paguyuban masyarakat ini, dimana setiap kali paguyuban melakukan sumbangan sukarela selalu di beritahu hasil yang di peroleh dengan seluruh masyarakat yang ada dalam paguyuban tersebut, selain itu setiap melakukan kegiatannya paguyuban selalu memberitahu dana keluar dan dana yang tersisa seperti yang di ungkapkan Bu Susi sebagai berikut: "Kalau masalah dana kita selalu terbuka, misalnya kalau baru meminta sumbangan sukarela maka di umumkan dana yang terkumpul seetelah itu kalau ada pengeluaran di beritahu lagi berapa dana yang keluar dan dana yang tersisa saat ini, jadi semua boleh tau gak ada yang di sembunyiin"

Berdasarkan hasil wawancara bersama Buk Susi bahwasannya paguyuban selalu memiliki laporan tentang berapa jumlah dana yang ada dan ketika ada pengeluaran pihak paguyuban juga menjelaskan berapa dana yang tersisa.

\section{Kerjasama (Cooperation)}

Kerjasama berarti melakukan kegiatan atau usaha yang dilakukan oleh beberapa orang untuk dapat mencapai suatu tujuan yang sama, terkait dengan Paguyuban masyarakat di Desa Petapahan Jaya berdasarkan pengamatan peneliti tingkat kerja sama yang di lakukan antar masyarakatnya sangat baik dalam melakukan pengembangan di SD Negeri 005 Petapahan Jaya sebagaimana hasil wawancara dengan Pak Ade sebagai berikut:"kami selalu bekerja sama dalam pengembangan fasilitas di sekolah ini, baik pengembangan sarana dan prasarana baik itu dana,tenaga mapun fikiran, kami saling membantu apa yang bisa kami lakukan kami lakukan secara bersamasama gak ada yang namanya sendiri-sendiri semua di lakukan secara bersama itu gunanya kami selalu musyawarah bersama baik masyarakat maupun pihak sekolah"

Berdasarkan hasil wawancara bersama Pak ade bahwasaanya dalam melakukan pengenmbangan sekolah di Desa Petapahan Jaya semua elemen masyarakatnya dilakukan secara bekerja sama baik itu dalam pendanaan maupun tenaga dan fikiran karena memang setiap hal yang dilkukan selalu melaui mustawarah sehingga tidak ada yang melakukan secara sendiri-sendri semua dilakukan secara bersama-sama. Pendapat yang senada juga disampaikan Bu Dorty sebagai berikut: "masyarakat dan sekolah dalam melakukan pengembangan sekolah selalu itu dilakakukan dengan bekerja sama bergotong royong sehingga kami pihak sekolah pun selalu ikut melakukan hal yang sama jadi tidak ada yang tidak sama-sama dalam pengembangan sekolah ini, semua dilakukan bersama-sama bergotong royong saling bantu membantu bahu-mambahu sehingga kami pihak sekolah merasa terbantu dan tertolonglah dengan yang dilakukan paguyuban masyarakat di Desa Petapahan Jaya ini dan masyarakatpun tenang menyekolahkan anaknya di sini karena tau bagaimana kondisi sekolahnya"

Berdasarkan hasil wawancara bersama Buk Dorty bahwasannya selama melakuakn pengembangan sekolah pihak sekolah dan masyarakat melakukankannya dengan bekerja sama bergotong royong dalam melakukannya sehingga selain pihak sekolah merasa terbantu pihak asyarakt juga merasa tenang menyokolahkan anaknya karena tau bagaimana keadaan sekolahnya dimana masyaralat melakukan itu semua untuk menciptakan sekolah yang baik supaya anak mereka juga dapat belajar dengan baik dan nyaman.

\section{Norma (Norm)}

Norma sosial akan sangat berperan penting dalam mengontrol bentuk-bentuk perilaku yang tumbuh dalam masyarakat, karena pengertian dari norma itu sendiri adalah sekumpulan aturan yang diharapkan dipatuhi dan diikuti oleh masyarakat pada suatu entitas tertentu dan didalam norma biasanya terdapat sanksi didalamnya, karena dengan begitu norma akan menentuka pola tingkah laku yang di harapkan dalam konteks hubungan sosial. Norma yang tumbuh di tengan masyarakat akan menentukan apakah norma tersebut akan memperkuat kerekatan hubungan antar individu dan memberikan dampak posistif bagi perkembangan masyarakat tersebut. 
Paguyuban masyarakat di Desa Petapahan Jaya dalam melakukan kegiatannya selalu dilakukan dengan bergotog royong dimana bergotong royong bagi Paguyuban masyarakat di Desa Petapahan Jaya merupakan warisan nilai-nilai kearifan lokal pada paguyuban masyarakat di Desa Petapahan Jaya. Gotong royong bagi Paguyuban Masrakat di Desa Petapahan Jaya merupakan modal sosial yang sangat penting bagi paguyuban masyarakat di Desa Petapahan Jaya ini, dan dalam pelaksanaannya apabila ada yang tidak mengikuti gotong royong maka akan mendapatkan sangsi sosial dimana sangsi sosial ini berupa pengucilan dan gosip menjadi pranata sosial yang berlangsung selama ini seperti yang diungkapkan Pak Nasrudin sebagai berikut:"karena kita disini melakukan segala sesuatunya dengan bergotong royong jadi, kalau ada yang sering sekali tidak ikut bergotong rotoyong itu yang menjadi masalah, masalhnya itu jadi yang tidak ikut bergotong rotong ini jadi bahan bicaraan, di kucilkan di sindir-sindir kalaupun ada nanti keperluannya ya gak banyak yang mau memntau juga kelihatan biasanya itu"

Berdasarkan hasil wawancara dengan Pak Nasrudin bahwasaanya gotong royong di Desa Petapahan Jaya ini juga sampai saat ini bisa terus berlangsung tidak terlepas dari sanksi sosial yang akan di terima masyarakat yang tidak ikut serta dalam pelaksanaan gotong royong dimana bisa jadi masyarakat tadi di kuciklan dari paguyuban masyarakat selain di kucilkan juga menjadi bahan pembicaraan bagi masyarakat lain. Norma tak tertulis ini disepakati sejak dulu hingga saat ini sehingga gotong royong pada paguyuban masyarakat di Desa Petapahan jaya ini masih terjaga dengan baik.

Gotong rotong menjadi warisan nilai-nilai kearifan lokal pada paguyuban Masyarakat di Desa Petapahan Jaya selain itu gotong royong pada paguyuban masyarakat di Desa Petapahan Jaya ini menjadi salah satu unsur modal sosial yang sangat penting pada masrakat, dimana dengan adanya gotong royong ini merupakan wujud aksi nyata dalam melakukan pengembangan di SD Negeri 005 Petapahan Jaya, dengan memberikan materi, tenaga dan juga fikiran sehingga meningkatkan kwalitas terutama dalam melakukan pengembangan fasilitas di SD Negeri 005 Petapahan Jaya.

\section{KESIMPULAN}

Upaya mewujudkan pendidikan yang berkualitas dapat dilakukan dengan kerjasama antar elemen baik pemerintah, swasta, dan masyarakat. Pelibatan masyarakat tidak hanya dalam bentuk bantuan fisik (capital) tetapi juga berwujud modal sosial (capital social). Modal sosial adalah sumber daya yang dapat dipandang sebagai investasi untuk mendapatkan sumber daya baru. Modal sosial paguyuban dalam mengembangkan fasilitas pendidikan di SD Negeri 005 Petapahan Jaya Kabupaten Kampar diantaranya yaitu (1) Modal sosial berupa Jaringan Sosial yang menumbuhkan partisipasi dan solidaritas masyarakat (2) Modal sosial berupa kepercayaan dalam bentuk kejujuran dan kerjasama (3) Modal sosial berupa norma yang dimiliki bersama.

\section{DAFTAR RUJUKAN}

Hermawan, Ida Kintamani Dewi. "The Performance of Equality Education As a Type of Non Formal." Jurnal Pendidikan Dan Kebudayaan, 2012.

Imron, Moh. Jamaluddin. "Manajemen Pembiayaan Sekolah.” Al-Ibroh, 2016.

Nurhadi, Arisal. "Manajemen Laboratorium Dalam Upaya Meningkatkan Mutu Pembelajaran.” Tarbawi: Jurnal Keilmuan Manajemen Pendidikan, 2018, doi:10.32678/tarbawi.v4i01.832.

Pariwisata, Dalam, et al. Model Partisipasi Masyarakat 2014. 2014.

Permendikbud RI No. 20. "Standar Kompetensi Lulusan Pendidikan Dasar Dan Menengah." Lampiran Peraturan Menteri Pendidikan Dan Kebudayaan Republik Indonesia Nomor 20 Tahun 2016, 2016.

Primadona. "Peranan Modal Sosial Dan Modal Manusia Dalam Wirausaha." Seminar Nasional Ekonomi Manajemen Dan Akutansi (SNEMA) Fakultas Ekonomi Universitas Negeri Padang, 2015.

Simarmata, Rajoki. Peran Modal Sosial Dalam Mendorong Sektor Pendidikan Dan Pengembangan Wilayah Di Kabupaten Samosir (Studi Pada Smk Hkbp Pangururan) Tesis Oleh Rajoki Simarmata 077003048/Pwd Sekolah Pascasarjana Universitas Sumatera Utara M E D A N 200 9. 2009, P. 129.

Sulistyorini, S. "Peranserta Masyarakat Dalam Pengembangan Sekolah Dasar." Jurnal Pendidikan Dan Pembelajaran Universitas Negeri Malang, vol. 18, no. 2, 2011, pp. 179-87.

Tim Kamus Badan Pengembangan dan Pembinaan Bahasa. "Leksikon." Badan Pengembangan Dan Pembinaan Bahasa, 2016. 